УДК 78.071.2(73=161.2)
DOI https://doi.org/10.31723/2524-0447-2020-31-2-3

Юлія Олександрівна Осмачко

ORCID: 0000-0002-3274-1888

аспірантка кафедри методики музичного виховання $і$ диригування

Навчально-наукового інституту музичного мистеитва

Дрогобицького державного педагогічного університету

імені Івана Франка

yuliaosmachko@ukr.net

\title{
ІСТОРИЧНІ ПЕРЕДУМОВИ ПОЯВИ КОГОРТИ УКРАЇНСЬКИХ ПІАНІСТІВ У ПІВНІЧНІЙ АМЕРИЦІ
}

Питання розвитку музичного мистецтва української діаспори є невід'ємною частиною національної музичної культури та освіти. Різноманітні соціальні й економічні труднощі, дві світові війни, полон, примусові вивезення, панування більщовицького тоталітарного режиму й стали тими історичними підставами для еміграції. Життя діаспори укладалося так, що частина українських емігрантів, зокрема й митиів, змушена була рятуватися виїздом за кордон. Більшість тих, хто оселився у США та Канаді, згодом стали невід'ємною складовою частиною населення цих країн. Саме північноамериканська українська діаспора належить до найбільш організованої національної меншини у світі з високим рівнем освіти і культури. Провідна роль у иьому доволі складному процесі належить українським митиям, зокрема піаністам, праия яких сприяла розквіту української музичної культури. Мета роботи полягає в розкритті історичних передумов появи українських піаністів на теренах Північної Америки. Методологія дослідження спирається на хронологічний та історичний методи, що дає змогу детально окреслити періоди становлення української діаспори в часовій послідовності. Наукова новизна полягає у більш глибокому вивченні передумов появи піаністів у діаспорі, їхнього життя та побуту, способів виживання, праці та, головне, мистецької діяльності. Висновки. Загалом усе багатство соціальних, освітніх, культурних та мистецьких надбань української діаспори Північної Америки засвідчує, що, незважаючи на доволі складні матеріальні та соціальні умови, музиканти-переселенці постійно підтримували музичну складову частину свого буття на чужині. У процесі розвитку музичного мистецтва та освіти діаспори вагому роль відіграли митиі, зокрема й піаністи, творчі здобутки яких мають важлливе історико-культурне значення не лише для національного, а й світового мистецького простору, а їхня яскрава педагогічна, концертна діяльність й активна громадянська позиція сприяють утвердженню української культури серед чужоземного населення.

Ключові слова: українська еміграція, закордонне українство, піаністи діаспори.

(C) Осмачко Ю. О., 2020 
Osmachko Yuliia Oleksandrivna, Postgraduate Student at the Chair of Methodology of Musical Upbringing and Conducting of the Institute of Music of the Drohobych Ivan Franko State Pedagogical University

Historical prerequisites for the emergence of a cohort of Ukrainian piano players in North America

The issue of development of musical art in the Ukrainian ümigrŭ environment is an integral part of the national musical culture and education. Miscellaneous social and economic hardships, two World Wars, POW camps, forced deportations orchestrated by the Bolshevik totalitarian regime have in fact become the historical reasons for emigration. The life in the Diaspora was organised in such a way that a part of Ukrainian ümigrŭs, including artists, were forced to escape prosecution by fleeing abroad. The predominant number of those who settled in the United States and Canada have ultimately become integral elements of the population of these countries. Ukrainian Diaspora in North America is one of the most organised, active, and vibrant ümigrŭ communities in the world, boasting a high level of education and cultural life. The leading role in this rather complicated process belongs to Ukrainian artists, including piano players, whose work contributed to the booming development of Ukrainian musical culture. The purpose of the article consists in revealing historical prerequisites that have enabled the emergence of a cohort of Ukrainian piano players in North America. The methodology of the research is based upon the chronological and historical methods which allow us to outline periods of emergence of Ukrainian Diaspora quite specifically, in great detail, over time. The scientific novelty consists in the in-depth research into the prerequisites that have contributed to the emergence of piano players in the Diaspora, defined their life and everyday habits, approaches to survival, work and - last but not the least - artistic activities. Conclusions. By and large, the opulence of social, cultural, and artistic heritage of North American Ukrainian ŭmigrŭs testifies to the fact that, all of the financial and social hardships notwithstanding, the Ukrainian ümigrŭ musicians kept cherishing the musical component of their new life in the New World. The process of development of musical art and education in the Diaspora was substantially assisted by artists - including piano players whose creative heritage have a substantial historical and cultural importance not only for the national but also for the global artistic space whereas their formidable teaching and concert activities as well as their active civil stance contribute to the establishment of the Ukrainian culture in a foreign land, in a foreign ethnic environment.

Key words: Ukrainian ŭmigrŭs, Ukrainians abroad, Diaspora piano players.

Актуальність теми дослідження. Багатство соціальних, освітніх, культурних мистецьких надбань представників діаспори засвідчує, що українська культура активно розвивається, формуючись навколо осередків збереження національної ідентичності нашого народу. Саме завдяки діаспорі в різні періоди зв’язки між Україною і світом розширювалися та міцніли, що 
значною мірою сприяло налагодженню всебічної взаємодії. 3 огляду на це нині важливим постає вивчення питань, пов'язаних з історією еміграції, особливо для української науки.

Однією з перших праць у галузі розкриття проблем української еміграції стала праця українського історика А. Шлепакова «Українська трудова еміграція в США і Канаді» (1960) [27]. Подібні дослідження з часом публікувалися істориками та соціологами з-поза меж України, серед них праці О. Войценка, Л. Винара, О. Воловиної, В. Ісаїва, М. Куропася, В. Маркуся, В. Маруняка, М. Марунчака, М. Мушинки та ін. Вивченням проблем української діаспори в Україні займалися В. Євтух, К. Кейданський, Б. Лановик, І. Срібняк, В. Трощинський та ін.

У праці відомого соціолога, доктора історії мистецтв Е. Сміта «Національна ідентичність» [18] доволі грунтовно розкривається сутність національної ідентичності та головні риси, що становлять основу національної самобутності та своєрідності. Дослідження В. Леника, С. Наріжного, Ю. Шевельова (Шереха), М. Боровика аналізують причини еміграції українців, їхнє політичне, громадсько-культурне та освітнє життя. Питань виникнення української діаспори та проблем і перспектив взаємовідносин закордонного українства та України на сучасному етапі торкаються у своїх працях А. Атаманенко [2], І. Ключковська та Н. Гумницька [9], Т. Цимбал [24].

Дослідженню культурного-мистецького, зокрема музичного, життя українських емігрантів присвячували свої праці Р. Савицький, Р. Савицький-мол. [17], 3. Лисько [11], I. Соневицький [19], Л. Обух [12], а розвитку культурно-музичних осередків української діаспори в країнах Північної Америки - В. Чайка [26]. Особливо цінною джерельною базою для розкриття різнобічного мистецького життя представників української діаспори є монографія та численні статті доктора мистецтвознавства Г. Карась [7].

Мета дослідження полягає в розкритті історичних передумов появи українських піаністів на теренах Північної Америки.

Наукова новизна дослідження полягає у більш детальному вивченні діяльності піаністів у діаспорі, їхнього життя та побуту, способів виживання та професійної праці.

Виклад основного матеріалу. Аналізуючи історичні етапи формування українських поселень поза межами нашої держави, можна стверджувати, що найбільш кількісною та орга- 
нізованою національною меншиною з високим рівнем освіти і культури у світі була північноамериканська діаспора, свідченням чого є створення широкої мережі організацій, зокрема освітніх, значна частина яких продовжує активно функціонувати і сьогодні.

Процес масової еміграції українців до країн Північної Америки наприкінці XIX - початку XX сторіччя зумовлений багатьма соціально-економічними чинниками, що призвело до зосередження на землях США та Канади сотень тисяч українських переселенців, історичний шлях яких нині тісно пов'язаний з історією цих країн. Характерною рисою представників української діаспори, що вирізняє їх серед інших народів, є те, що вони, «будучи відірваними від рідної землі, не поривали з нею зв'язків, зберігали демократичні традиції національної культури» [27, с. 3]. Традиційно історики виокремлюють чотири хвилі української еміграції до країн Північної Америки, щоправда, деякі науковці у своїх працях пропонують вдосконалити обрахунок еміграційних хвиль і вважати четвертою еміграцію, що пов'язана 3 «хрущовською відлигою», а сучасну еміграцію - п'ятою хвилею [2, с. 7-8].

Перша хвиля масової еміграції українців, спричинена безробіттям та значним перенаселенням українських земель, розпочалася у 1861 році і тривала аж до початку Першої світової війни, привівши за океан понад 180 тисяч українців переважно з Західної України, котрі зосереджувалися у степах Західної Канади, де була найбільша потреба в дешевій робочій силі [21, с. 29-30].

Музичне мистецтво української діаспори того часу було аматорським та представлене «прогресивними організаціями», які являли собою поєднання музичного, театрального, танцювального мистецтва та концертної діяльності. Оскільки професійних музикантів у діаспорі не було, роль організаторів музичних вистав виконували більш освічені активісти, до грона яких належать: організатор культурно-освітньої та громадської діяльності у Вінніпезі, ініціатор створення читальні ім. Т. Шевченка, фундатор української газети «Канадійський фармер» - К. Геник та Л. Антонюк, котрі одні 3 перших налагодили мистецьку діяльність у діаспорі, здійснивши театральну постановку вистави «Аргонавти» у Вінніпезі в 1904 році та також організувавши концерт на пошану Т. Шевченка [7, с. 223-224]. 
Після Першої світової війни, розпаду Австро-Угорської імперії, окупації українських територій та ускладнень економічної ситуації у 1920-1930 роках за океан подалась друга хвиля українських емігрантів, серед яких були не лише селяни, а й представники інтелігенції, ветеранських армійських кіл Української Народної Республіки. Всі вони, живучи в Україні, брали активну участь у культурно-мистецькому та громадському житті. Будучи учасниками та організаторами різноманітних драматичних гуртків і творчих колективів, маючи певний досвід, вони активно сприяли піднесенню виконавського мистецтва діаспори на новий рівень.

Міжвоєнний період у Канаді позначався доволі активною творчою діяльністю професійних солістів-виконавців, серед них: піаніст I. Мельник, скрипалі I. Кучмій, К. Гайовська, брати Т. та Б. Губицькі, віолончелісти Л. та Н. Новак; скрипалька С. Лазарович; відома українська співачка С. Крушельницька. Незадовго до початку Другої світової війни 3 концертами до Канади приїздили відомі українські митці В. Ємець (1936, 1939), П. Конопленко-Запорожець, Л. Гайдамака [6, с. 40], композитори і виконавці А. Рудницький (1938-1939), Є. Турула, П. Маценко, Я. Козарук, Л. Колесса, М. Голинський, М. Сокіл, Т. Кошиць, співаки хору і послідовники О. Кошиця - Ю. Гассан, Л. Сорочинський та інші, виступи яких, безумовно, показали іноземним слухачам доволі високий професійний рівень українського музичного мистецтва [7, с. 224-226].

3 початком Другої світової війни мільйони українців, зокрема й митців, у зв'язку з жорсткими утисками та переслідуванням радянської влади змушені були рятуватися еміграцією, а деякі з них, потрапивши під репатріацію, були примусово вивезені на роботи до Німеччини.

Із завершенням Другої світової війни та розподілом німецьких земель більшість емігрантів потрапили під «відозву» та змушені були повертатися до своїх домівок, проте переселенці з України категорично відмовлялися від насильного вивезення та, шукаючи захисту, створювали відповідні табори, в яких розміщувалися численні громади українців, 3 офіційною названою «табори переміщених осіб». Такого роду поселення формувались переважно в західних зонах Німеччини, Австрії, Італії та на той час налічували понад 161 табір, серед них табори Аугсбурга, Ашафенбурга, Берхтенсгадена, 
Ганау, Ляйпгайма, Міттенвальда, Ноймаркта, Регенсбурга, Трауншейна, Гіссена, Фюрта та багатьох інших міст, при яких активно діяли церкви, організовувались хори, народні та музичні школи, театри, створювались мистецькі спілки, серед яких Об'єднання українських музик (ОУМ) (1946) та Українська спілка образотворчих мистецтв (Мюнхен, 1947), де часто організовувались виставки, концерти та різноманітні культурні заходи [20, с. 72-73]. Загалом таборова структура суттєво відрізнялася від існуючої в Україні, оскільки частка представників інтелігенції тут була значно вищою. Власне, до цієї групи переміщених осіб належали митці, котрі й сприяли активному розгортанню музично-культурного життя в табоpax. До їх числа належать піаністи: Роман Савицький - організатор та очільник музичних шкіл у таборах Карлсфельда та Берхтесгадена (1945-1949) [3]; Василь Шуть - активний учасник усіх культурно-мистецьких заходів та вчитель фортепіано у Ганновері; В. Безкоровайний - один з організаторів культурного життя у таборах, засновник хору; Ігор Білогруд, котрий читав приватні лекції та інші.

У 1950-х роках більшість українців після тривалого перебування у таборах опинилася за океаном й одразу розпочала активну роботу над створенням відповідних умов для розвитку громадського, наукового та культурного-мистецького життя. Свідченням цього є багатоманіття соціальних, освітніх, культурних та мистецьких надбань, що вражає масштабами. Серед них чільне місце належить Українському Інституту Америки (США, 1948), на чолі з українським винахідником та бізнесменом Вільямом Джусом, котрий сприяв поширенню української культури серед чужоземного населення, розбудові мистецьких зв'язків із широкими колами американського світу, організатором мистецьких виставок, наукових з’їдів, концертів, літературних вечорів, доповідей та товариських зустрічей [23, с. 1]. 3 метою збереження національної ідентичності українського народу та популяризації української культури серед американського населення УІА налагодив тісну співпрацю з Українською Вільною Академією Наук та Науковим товариством імені Тараса Шевченка, котра стала важливим елементом діяльності інституту [9].

Не можна оминути увагою й Українську Вільну Академію Наук, засновником якої є когорта українських вчених-емігрантів на чолі з Дмитром Дорошенком (Авгсбург 1945). 
Згодом Академія була перенесена до Канади, а з 1950 року розпочала свою діяльність й у Нью-Йорку. Загалом Українська Вільна Академія Наук Канади поділяється на інститути та комісії, має власну бібліотеку й архів, а також публікує cepiï «Slavistica», «Onomastica», «Ukrainica Canadiana», «Українські вчені» (1949-1961). Окрім того, академія видала «Кобзар» Тараса Шевченка за редакцією Леоніда Білецького у чотирьох томах (1952-1954), «Матеріали до українськоканадської фольклористики і діалектології» (1956-1963); «An Etymological Dictionary of Ukrainian Language» Ярослава Рудницького (1962), «Історію українців Канади» Михайла Марунчака (1968), «History of the Ukrainian Literature in Canada» Микити Мандрики (1968), «Ювілейний збірник» (1976) та багато інших [1]. Говорячи про канадську Вільну Академію Наук, доречно буде також згадати й про Українську Вільну Академію Наук у США, основним мистецьким надбанням якої став Музей-Архів, фонд якого налічував близько 13 тисяч книг, кілька десятків тисяч періодичних видань, кілька сотень картин та скульптур та надзвичайно багату українознавчу бібліотеку [15]. Крім вищезгаданих, тут функціонує ціла низка інших організацій, серед яких Український Конгресовий Комітет Америки (1940), Наукове товариство ім. Т. Шевченка (1950), Українське історичне товариство, Товариство українських інженерів Америки, Українське лікарське товариство Північної Америки, Товариство українсько-американських адвокатів та багато інших [10], що є свідченням високого рівня освіти та культури українських емігрантів.

Діаспоряни активно створювали й культурно-відпочинкові центри, як-от «Союзівка» та «Гантер» із Центром Української Культури (Music and Art Center of Greene County) (1977), де проводилися фестивалі, концерти класичної музики, виставки та інші культурно-мистецькі заходи. Серед них «Фестиваль класичної та камерної музики» (1983), який сьогодні вважається найстарішим і наймасштабнішим фестивалем «серйозної музики» в Greene County (штат Нью-Йорк) [8] та «Фестиваль української музики», під орудою І. Соневицького, що об'єднали у творчій співпраці професійних музикантів, серед яких композитори М. Скорик, В. Балей, вокалісти М. Стеф'юк, Я. Гнатюк, О. Кровицька, піаністи Д. Гординська-Каранович, В. Винницький, М. Сук, О. Слободяник, Л. Крупа, Ю. Осінчук, І. Колодій, Т. Гриньків Т. Чекіна, Л. Артимів, 
В. Курпій, О. Цибрівська, Н. Богачевська, скрипалі О. Криса, Т. Чекаліна, Ю. Мазуркевич, С. Сорока та тріо «Кантилена», під керівництвом піаніста Ю. Цибрівського [25, с. 3].

Українські педагоги-музиканти, працюючи в Україні в різних навчальних закладах, приїздили до США, маючи достатній досвід, певні музично-освітні традиції та тверде переконання щодо потреби і переваги шкільного навчання над приватно-індивідуальним. Таким чином, об'єднавшись на чолі з українським піаністом, педагогом і музичним критиком Р. Савицьким (1907-1960), вони створили шкільну організацію - Український Музичний Інститут Америки (1952), котрий згодом посів одне із чільних місць серед американських навчальних музичних закладів того часу [11, с. 3]. Перше десятиліття існування УМІ можна охарактеризувати як період об'єднання українських приватних музичних навчальних закладів в одну організацію та розширення мережі філій на центри українського поселення [13, с. 73]. Загалом учительський склад УМІ формували провідні музиканти, мистецька праця яких грунтувалася не лише на педагогічній діяльності, а й на активному концертному житті. До числа педагогів УМІ належать композитори - Я. Барнич, В. Грудин, В. Безкоровайний, І. Білогруд, В. Кіпа, М. Фоменко, М. Недзведський, В. Шуть, музикознавці - В. Витвицький, І. Соневицький, 3. Лисько, О. Залеський, Б. Кушнір, О. Лиховид. Р. Шуль, диригенти - Б. Волянська, Ю. Оранський, Р. Ставничий, вокалісти - К. Чічка-Андрієнко, І. Приймова, О. Геймур, А. Добрянський, Л. Костецька, М. Кокольська-Мосійчук, М. Лисогір, скрипалі - В. Цісик, Р. Венке, Б. Марків, О. Сімович, В. Тритяк, С. Цегельський, піаністи - Р. Савицький, Д. Каранович, А. Рудницький, М. Байлова, В. Кіпа, О. Ясеницька-Волошин, Г. Лагодинська-Залеська, Т. Богданська, Ю. Цибрівський, Л. Горницький, І.-Н. Решетилович, О. Ейдельман, Л. Шав'як, Т. Гриньків, О. Чипак, Н. Котович, Н. Недільська-Слободян, О. Наконечна-Сушко, В. Балей, Ю. Цибрівський, О. Слободяник, Ю. Осінчук, Л. Крупа, Р. Рудницький, М. Шлемкевич-Савицька, М. Цісик, Б. Лончина, Б. Перфецький та інші [17, с. 172].

Назагал УМІ пройшов доволі довгий і не простий шлях своєї діяльності, однак його педагоги навіть у складних умовах зуміли продуктивно працювати, про що свідчить яскраве концертне життя учнів та викладачів УМІ, запровадження 
нових методик, систем, способів та методів викладання, які широко використовувалися в навчальному процесі. До числа вчителів, які активно займалися дослідженням проблем виховання піаніста-початківця, належить Р. Савицький, який у своїй праці «Основні засади фортепіанної педагогіки» [16] чітко та лаконічно висвітлює особливості роботи з піаністами-початківцями.

Також тут варто згадати Д. Гординську-Каранович та ii працю «Проблеми музичного виховання», в якій як довголітній практик авторка поділилася порадами, зауваженнями та підходами до роботи з учнями-початківцями [5, с. 3]. Вагомою стала і іiі праця «3 педагогічних спостережень» (1968) [4], в якій приділено значну увагу методиці індивідуальної роботи з учнями, розвитку їхньої зацікавленості музичним мистецтвом, подано власний приклад педагога як виконавця та зауваження і поради педагогам-початківцям, при цьому за основу взято провідні методики піаністів-педагогів Г. Нейгауза, С. Рахманінова, Ф. Шопена [12, с. 111].

Цінною для педагогічної науки є й праця Л. Горницького, що грунтувалася на порівняльному аналізі різних методик та полягала в застосуванні психосемантичного прийому, в основі якого лежала побудова та розв'язання центрів асоціацій, що керують підсвідомими рухами.

Вагоме місце у становленні мистецького життя українських емігрантів належало також Музичному інституту ім. М. Лисенка в Торонто, засновником якого став відомий скрипаль, диригент, письменник та педагог Іван Ковалів. Важливим здобутком Музичного інституту стала організація, за підтримки Преосвященного Ізидора Борецького, струнного оркестру, який розпочав свою творчу діяльність у 1955 році. До складу оркестру увійшли найбільш здібні учні класу I. Коваліва. Репертуар оркестру складався з понад 60 творів світових композиторів, від барокових до сучасних. За період своєї творчої праці оркестр дав близько 60 концертів як у Канаді, так і в американських культурних центрах, зокрема у Нью-Йорку, Філадельфії, Детройті, Клівленді, Чикаго та інших [14]. Інститут став осередком творчої праці не лише I. Коваліва, також тут працювали віолончелістка Х. Колесса, скрипаль та контрабасист Л. Білошицький, піаністи К. Гвоздецька, А. Ярошевич, М. Кравців-Барабаш, О. Бризгун, хореограф О. Заклинська та диригент Л. Туркевич. Варто зазна- 
чити, що більшість вищезгаданих навчальних закладів США та Канади продовжують свою діяльність і сьогодні, виховуючи нове покоління талановитих фахівців не тільки у сфері мистецтва, а й різних галузей.

Загалом через складну політичну ситуацію в Україні в еміграції у XX столітті опинилося чимало музикантів, у тому числі й піаністів, котрі представляли різні виконавські школи та стилі. Серед них у США провадили свою діяльність В. Горовиць, В. Грудин, В. Кіпа, Б. Максимович, I. Білогруд (Наддніпрянська Україна), Д. Гординська-Каранович, А. Рудницький, Р. Савицький, Г. Лагодинська-Залеська, Б. Перфецький, Л. Луців-Лєвакова, Л. Горницький (Західна Україна), М. Фоменко (харківська фортепіанна школа), в Канаді - В. Доброліж та Ю. Фіала (Наддніпрянська Україна), Л. Колесса, М. Кравців-Барабаш (Західна Україна) [7, с. 406].

Молодша генерація піаністів представлена такими постатями, як Ю. Олійник (1931 р. н.), В. Балей (1938 р. н.), О. Слободяник (1941-2008), Р. Рудницький (1942 р. н.), М. Сук (1945 р. н.), Л. Артимів (1954 р. н.) - випускниця УМІ у Філадельфії (клас. Ю. Оранського), Ю. Осінчук (1953 р. н.) випускниця класу Р. Савицького, В. Винницький (1955 р. н.), Б. Сперкач, Р. Дурзо, І. Пелех-Зварич, Л. Крупа (1956 р. н.) - випускниця класу педагога Д. Гординської-Каранович, О. Луцишин (1964 р. н.), Н. Шпаченко (1977 р. н.) - США; у Канаді свою творчу діяльність провадять Н. Несторовська, М. Сас та багато інших. Більшість із них продовжує творчу та педагогічну працю в різних куточках Північної Америки. Зокрема, Л. Крупа провадить свою мистецьку діяльність в УМІ у Нью-Йрку, працюючи педагогом та ведучи активне концертне життя; В. Винницький виступає з концертами у США (Нью-Йорк, Чикаго, Філадельфія, Бостон, Вашингтон); О. Луцишин веде активне концертне життя, виступаючи у престижних залах США, Канади, Німеччини та ін. [7, с. 425-427]. А видатна піаністка та композиторка сучасності Н. Шпаченко цьогоріч стала лауреатом міжнародної премії «Греммі 2020» у номінації «Найкраща класична збірка». Її альбом «The Poetry of Places», який піаністка записала разом із Джоенн Пірсом Мартіном, Ніком Террі та Корі Хіллз, номінувався на Греммі-2020 у двох номінаціях: «Найкраща класична збірка», а також «Продюсер року (класика)». У першій таки здобув перемогу [22]. Зараз Н. Шпа- 
ченко - професор фортепіано в Політехнічному університеті штату Каліфорнія.

Висновки. Підсумовуючи, можна стверджувати, що, попри доволі складне матеріальне і соціальне становище та жорстокі утиски з боку влади, українська музична культура набула активного розквіту і важлива роль у цьому процесі, безперечно, належить піаністам, котрі увійшли в історію не лише українського мистецтва, а й світу загалом, завдяки своїй педагогічній праці, різного роду мистецькій практиці та постійній пропаганді української музики в чужоземному середовищі.

\section{СПИСОК ЛІТЕРАТУРИ}

1. 70 років тому у Канаді почала діяльність Українська Вільна Академія Наук. URL: https://www.ukrinform.ua/rubric-diaspora/ 2658709-70-rokiv-tomu-u-kanadi-pocala-dialnist-ukrainska-vilnaakademia-nauk.html.

2. Атаманенко А. Закордонне українство та Україна: проблеми та перспективи взаємовідносин. Наукові записки Національного університету «Острозька академія». Історичні науки. 2015. Випуск 23. С. 7-13.

3. Воробкало Д. Віртуоз чорно-білих клавіш. URL: https://zbruc.eu/node/63359.

4. Гординська-Каранович Д. 3 педагогічних спостережень. Bicmi (Міннеаполіс, США). 1968. Ч. 4. С. 18.

5. Д. Гординська-Каранович обрана президентом УМІ. Свобода. 1986. Ч. 199. 17 жовтня. С. $1,3$.

6. Дутчак В. Бандурне мистецтво українського зарубіжжя як національно-культурний феномен XX - початку XXI століть. Bicник Львівського університету. Мистецтвознавство. 2015. Випуск 16. Ч. 2. C. $34-47$.

7. Карась Г. Музична культура української діаспори у світовому часопросторі XX століття : монографія. Івано-Франківськ : Тіповіт, 2012. $1164 \mathrm{c}$.

8. Карась Г. Семіосфера націокультурного простору Гантера. Вісник Киїського національного університету культури $і$ мистецтв. Серія: Музичне мистецтво. Випуск 3 (1). 2020. С. 8-17.

9. Качковська Г. Український інститут Америки - одна з візитівок української діаспори в CША. URL: http://ukrainianchi.com/\%D1\% 83\%D0\%BA\%D1\%80\%D0\%B0\%D1\%97\%D0\%BD\%D1\%81\%D1\%8C\% D0\%BA\% D0\%B8\% D0\%B9-\%D1\%96\% D0\%BD\%D1\%81\%D1\%82\% D0\% B8\% D1\%82\%D1\%83\% D1\%82-\% D0\%B0\% D0\%BC\%D0\%B5\% $\mathrm{D} 1 \% 80 \% \mathrm{D} 0 \% \mathrm{~B} 8 \% \mathrm{D} 0 \% \mathrm{BA} \% \mathrm{D} 0 \% \mathrm{~B} 8-\% \mathrm{D} 0 \% \mathrm{BE} \% \mathrm{D} 0 \% \mathrm{~B} 4 \% \mathrm{D} 0 \%$ $\mathrm{BD} \% \mathrm{D} 0 \% \mathrm{~B} 0-\% \mathrm{D} 0 \% \mathrm{~B} 7-2 /$

10. Ключковська I., Гумницька Н. Українська діаспора в об'єктиві сучасності - національно-політичний та духовно-культурний феномен. URL: http://storinka-m.kiev.ua/article.php?id=303. 
11. Лисько 3. Український музичний інститут в Америці. Пропам'ятна Книга Українського Музичного Інституту в Америці 3 нагоди десятиліття його існування [видавничий референт УМІ Ігор Соневицький]. New-York D.N.: East Side Press, 1963. 77 с.

12. Обух Л. Український Музичний Інститут Америки: збереження традицій вітчизняної музичної освіти та перспективи розвитку. Наукові записки Тернопільського національного педагогічного університету імені Володимира Гнатюка. Серія: Мистеитвознавство. 2012. № 3. С. $108-114$.

13. Осмачко Ю. Освітні аспекти діяльності Українського музичного інституту Америки. Springs cientific reading. XXIX International Scientific and Practical Conference.Vinnytsia (Ukraine), 15 April 2019. part 6. C. $70-80$.

14. Паттен I. Торонто відзначає творчу працю Івана Коваліва у 100-ліття його народження. Новий шлях. Українські вісті. 1 листопада. 2016. URL: https://www.newpathway.ca/\%D1\%82\% D0\% BE\% D $1 \% 80 \%$ D0\%BE\% D0\% BD\% D 1\%82\% D0\%BE-\% D0\% B 2\% D $1 \% 96 \%$ D 0\% B 4\% D 0\% B 7\% D 0\% B D \% D 0\% B 0\% D 1\%87\% D0\% B $0 \%$ D $1 \% 94-\%$ D $1 \% 82 \%$ D0\% B2\% D0\% BE\% D $1 \% 80 \%$ D $1 \% 8$ $7 \% \mathrm{D} 1 \% 83-\% \mathrm{D} 0 \% \mathrm{BF} \% \mathrm{D} 1 \% 80 \% \mathrm{D} 0 \% \mathrm{~B} 0 \% \mathrm{D} 1 \% 86 \% \mathrm{D} 1 \% 8 \mathrm{E}-\% \mathrm{D} 1 \%$ $96 \% \mathrm{D} 0 \% \mathrm{~B} 2 \% \mathrm{D} 0 \% \mathrm{~B} 0 \% \mathrm{D} 0 \% \mathrm{BD} \% \mathrm{D} 0 \% \mathrm{~B} 0 /$

15. Писаренко I. 3 історії створення Української Вільної Академії Наук. URL: http://www.happymisto.od.ua/journalism/z-istori\%D1\%97stvorennya-ukra\% D $1 \% 97$ nsko\% D $1 \% 97$-vilno\% D $1 \% 97$ akademi\%D1\%97-nauk.

16. Савицький Р. Основні засади фортепіанної педагогіки. Львів, 1994. 39 c.

17. Савицький Р.-мол. Музика як представник народу. Альманах УНС. 2002. С. 169-174.

18. Сміт Е. Національна ідентичність. Київ : Основи, 1994. 224 с.

19. Соневицький I. Дирекція Українського музичного інституту. Пропам'ятна Книга Українського Музичного Інституту в Америці з нагоди десятиліття його існування [видавничий референт УМІ Ігор Соневицький]. New-York D.N.: EastSidePress, 1963. 77 с.

20. Стрільчук Л. Просвітницька діяльність української інтелігенції в таборах для переміщених осіб у західних окупаційних зонах (1944-1951 рр.). Науковий вісник Східноєвропейського національного університету імені Лесі Українки. Розділ І. «Просвіта» в суспільно-політичному житті України. Випуск 3. 2016. С. 69-74.

21. Трощинський В., Шевченко А. Українці в світі. Київ, 1999. $351 \mathrm{c}$.

22. Українка отримала премію Греммі. URL: https://nv.ua/ukr/ style/kultura/ukrajinka-otrimala-gremmi-2020-50066450.html

23. Український Інститут одержав меморіяльну плиту історичної пам'ятки. Свобода. 1980. Ч. 245. 21 листопада. С. $1,7$.

24. Цимбал Т. Феномен еміграції: досвід філософської рефлексії : авторефер. дис. ... докт. філос. наук : 09.00.03. Київ, 2012. 38 с. 
25. Центр Української Культури. Свобода.1996. Ч. 92. 16 травня. C. 3 .

26. Чайка В. Розвиток культурно-музичних осередків української діаспори в країнах Північної Америки кінця XX - початку XXI ст. Вчені записки ТНУ імені В. І. Вернадського. Серія: Історичні науки. 2018. Том 29 (68). № 2. С. 26-30.

27. Шлепаков А. Українська трудова еміграція в США та Канаді (кінець XIX - початок XX ст.). Київ : Видавництво Академії наук Української РСР. 1960. 199 с.

\section{REFERENCES}

1. The Ukrainian Free Academy of Sciences started operating in Canada 70 years ago. URL: https://www.ukrinform.ua/rubric-diaspora/2658709-70-rokiv-tomu-u-kanadi-pocala-dialnist-ukrainska-vilna-akademia-nauk.html [in Ukrainian].

2. Atamanenko A. (2015) Foreign Ukrainians and Ukraine: problems and prospects of relations. Scientific notes of the National University «Ostroh Academy». Historical sciences. Vol 23. P. 7-13. [in Ukrainian]

3. Vorobkalo D. Virtuoso of black and white keys. URL: https://zbruc.eu/node/63359 [in Ukrainian]

4. Hordynska-Karanovych D. (1968) From pedagogical observations. Visti (Minneapolis, USA). Issue. 4. P. 18. [in Ukrainian].

5. D. Hordynska-Karanovych was elected president of UMI (1986). Svoboda. Vol. 199. P. 1, 3. [in Ukrainian].

6. Dutchak V. (2015) Bandura art of Ukrainian abroad as a national and cultural phenomenon of the XX - early XXI centuries. Visnyk Bulletin of Lviv University. art history. Issue 16. Part 2. P. 34-47. [in Ukrainian].

7. Karas H. (2012) Musical culture of the Ukrainian diaspora in the world time space of the twentieth century: monograph. Ivano-Frankivsk: Tipovit. [in Ukrainian].

8. Karas H. (2020) Semiosphere of Hunter's national-cultural space. Bulletin of Kyiv National University of Culture and Arts. Series: Musical art. Issue 3 (1). P. 11. [in Ukrainian].

9. Kachkovska H. Ukrainian Institute of America - one of the hallmarks of the Ukrainian diaspora in the United States. URL: http://ukrainianchi.com/ $\% \mathrm{D} 1 \% 83 \% \mathrm{D} 0 \% \mathrm{BA} \% \mathrm{D} 1 \% 80 \% \mathrm{D} 0 \% \mathrm{~B} 0 \% \mathrm{D} 1 \% 97 \% \mathrm{D} 0 \% \mathrm{BD} \% \mathrm{D} 1 \% 81 \%$ D $1 \% 8$ C \% D $0 \%$ B A \% D $0 \%$ B $8 \%$ D $0 \%$ B 9- \% D $1 \% 96 \%$ D $0 \%$ B D \% D $1 \% 81 \%$ D $1 \% 82 \%$ D0\% B 8\% D 1\%82\% D 1\%83\% D 1\%82-\% D0\% B0\% D0\%BC\% D0\% B5\% D1\%80\% D0\% B8\% D0\%BA\% D0\%B8-\%D0\% BE\%D0\%B4\%D0\%BD\%D0\%B0-\% D0\%B7-2/ [in Ukrainian].

10. Kliuchkovska I. Humnytska N. Ukrainian diaspora in the lens of modernity - a national-political and spiritual-cultural phenomenon. URL: http://storinka-m.kiev.ua/article.php?id=303 [in Ukrainian].

11. Lysko Z. (1963) Ukrainian Music Institute in America. Commemorative Book of the Ukrainian Music Institute in America on the occasion of the tenth anniversary of its existence [UMI publishing officer Ihor Sonevytsky]. New-York D.N .: East Side Press [in Ukrainian]. 
12. Obukh L. (2012) Ukrainian Music Institute of America: preservation of traditions of domestic music education and prospects for development. Scientific notes of Ternopil National Pedagogical University named after Volodymyr Hnatyuk. Series: Art History. № 3. P. 108-114. [in Ukrainian].

13. Osmachko Yu. (2019) Educational aspects of the Ukrainian Music Institute of America. Springs cientific reading. XXIX International Scientific and Practical Conference.Vinnytsia (Ukraine), 15 April. Part 6. P. 70-80. [in Ukraine].

14. Patten I. (2016) Toronto celebrates the creative work of Ivan Kovalev on the 100th anniversary of his birth. A new way. Ukrainian news. November 1. URL: https://www.newpathway.ca/ $\% \mathrm{D} 1 \% 82 \% \mathrm{D} 0 \% \mathrm{BE} \% \mathrm{D} 1 \% 80 \% \mathrm{D} 0 \% \mathrm{BE} \% \mathrm{D} 0 \% \mathrm{BD} \% \mathrm{D} 1 \% 82 \% \mathrm{D} 0 \% \mathrm{BE}-\%$ D0\%B2\%D1\%96\%D0\%B4\%D0\%B7\%D0\%BD\%D0\%B0\%D1\%87\%D0 \%B0\%D1\%94-\%D1\%82\%D0\%B2\%D0\%BE\%D1\%80\%D1\%87\%D1\%83 -\%D0\%BF\%D1\%80\%D0\%B0\%D1\%86\%D1\%8E-\%D1\%96\%D0\%B2\% D0\%B0\%D0\%BD\%D0\%B0/ [in Ukrainian].

15. Pysarenko I. From the history of the Ukrainian Free Academy of Sciences. URL: http://www.happymisto.od.ua/journalism/z-istori\% D $1 \% 97$-stvorennya-ukra\% D $1 \% 97$ nsko\% D $1 \% 97$-vilno\%D $1 \%$ 97-akademi\%D1\%97-nauk [in Ukrainian].

16. Savytskyi R. (1994) Basic principles of piano pedagogy. Lviv. [in Ukrainian].

17. Savytskyi R.-mol. (2002) Music as a representative of the people. Almanac of UNS. P. 169-174. [in Ukrainian].

18. Smit E. (1994) National identity. Kyiv: Osnovy. [in Ukrainian].

19. Sonevytskyi I. (1963) Directorate of the Ukrainian Music Institute. Commemorative Book of the Ukrainian Music Institute in America on the occasion of the tenth anniversary of its existence [UMI publishing officer Ihor Sonevytsky]. New-York D.N.: EastSidePress [in Ukrainian].

20. Strilchuk L. (2016) Educational activities of the Ukrainian intelligentsia in camps for displaced persons in the western occupation zones (1944-1951). Scientific Bulletin of the Lesia Ukrainka East European National University. Section I. «Education» in the socio-political life of Ukraine. 3. P. 69-74. [in Ukrainian].

21. Troshchynskyi V., Shevchenko A. (1999) Ukrainians in the world. Kyiv. [in Ukrainian].

22. The Ukrainian received a Grammy Award. URL: https://nv.ua/ ukr/style/kultura/ukrajinka-otrimala-gremmi-2020-50066450.html [in Ukrainian].

23. The Ukrainian Institute received a memorial plaque of a historical monument (1980). Svoboda. Vol. 245. P. 1, 7. [in Ukrainian].

24. Tsymbal T. (2012) The phenomenon of emigration: the experience of philosophical reflection: author. dis. for science. degree of Dr. philos. Sciences: 09.00.03. Kyiv. [in Ukrainian].

25. Center of Ukrainian Culture (1996). Svoboda. Vol. 92. P. 3. [in Ukrainian]. 
26. Chaika V. (2018) Development of cultural and musical centers of the Ukrainian diaspora in North America in the late XX - early XXI centuries. Scientific notes of TNU named after VI Vernadsky. Series. Historical sciences. Volume 29 (68). № 2. P. 26-30. [in Ukrainian].

27. Shlepakov A. (1960) M. Ukrainian labor emigration to the United States and Canada (late nineteenth - early twentieth century.). Kyiv: Vydavnytstvo Akademii nauk Ukrainskoi RSR. [in Ukrainian].

УДК 784.4.011.26.03:398.8:392.5

DOI https://doi.org/10.31723/2524-0447-2020-31-2-4

\section{Надія Анатоліївна Лисевич}

ORCID: 0000-0002-1794-3510

аспірантка кафедри музикознавства та хорового мистецтва факультету культури та мистецтва

Львівського національного університету імені Івана Франка lisevichnadia@gmail.com

\section{КУЛЬТУРНІ ЗВ'ЯЗКИ ЕТНІЧНИХ УКРАЇНЦІВ ПІВДЕННОЇ БЕССАРАБІЇ 3 ІНШИМИ НАРОДАМИ (НА ПРИКЛАДІ ВЕСІЛЬНОГО ОБРЯДУ)}

Мета роботи - дослідження весільного обряду етнічних українців Південної Бессарабії, виокремлення питомих елементів ритуалу від культури інших народів. Методологія дослідження спирається на комплексний метод, що включає принципи історизму, порівняльної типології. Використання комплексного методу, цілісного опису об'єктів $є$ обов'язковим для дослідження, тому що розкриває взаємопов'язаність елементів, притаманну фольклору. Наукова новизна - розгляд культури етнічних українців Південної Бессарабії як контактної з культурою інших народів; спроба осмислити символічність елементів, атрибутів весілля насамперед української традииії, вивчення культури бессарабської української традиції в комплексі з традиціями інших, сусідніх, народів. Дослідженню передувала фольклористична експедиція селами та містечками Бессарабії (колишні Кілійський, Татарбунарський, Саратський райони Одеської області), воно здійснювалося як за аналітичним опрацюванням уже опублікованих матеріалів науковців $i$ збирачів фольклору, так $i$ за матеріалами власних польових досліджень. Висновки. Культура Південної Бессарабії - ие самобутне явище, що потребує комплексного підходу до вивчення. Музичний обрядовий фоль-

(C) Лисевич Н. А., 2020 